\title{
$\angle$ Research Square

\section{Monitoring of dairy farm management practice and production performances using Structural Equation Modeling in Amhara region, Ethiopia}

Malede Birhan Atanaw ( $\square$ maledebir@gmail.com )

Bahir Dar University https://orcid.org/0000-0003-3410-4150

Yeshambel Mekuriaw Chekol

Bahir Dar University

Asaminew Tassew Wolde

Bahir Dar University

Firew Tegegne Amogne

Bahir Dar University

\section{Research Article}

Keywords: Monitoring, dairy farm, management practice, structural equation modeling

Posted Date: February 28th, 2022

DOI: https://doi.org/10.21203/rs.3.rs-1324991/v1

License: (9) This work is licensed under a Creative Commons Attribution 4.0 International License. Read Full License 


\section{Abstract}

Structural equation modeling (SEM) was employed to monitor the dairy management practice and dairy production performance in Amhara region. Data was collected from 117 dairy farms on frontal interview on cluster sampling approaches to identify respondents. The model result revealed that the relationship between construct reliabilities and the dairy farm facilities was significantly varies $(p<0.01)$. The model analysis showed that the level of education has a positive and statistically significant relationship with the reproduction performance of dairy farms, with a correlation value of $(\rho=0.337)$, moreover, the gross revenue of the farm showed as $(r=0.849)$. Farm gross revenue articulated a positive, strong, and statistically significant association with feed and nutrition indicated value (0.906), dairy farm facilities ( $\rho$ $=0.934)$, hygiene and waste management (0.921). As a consequence, the predictors of dairy farm facilities feed and nutrition and hygiene and waste management explained 93.40, 84.0, 80.20 and 88.50\% of the variance. From the study it can be concluded that, the proposed model is valid and training and education have an effect on farm management practices, subsequently affects the productive performance of dairy farm in Amhara region. Therefore, the researchers are recommending to regional agriculture and extension offices and other concerned organization to monitor the sector and provide appropriate training and awareness to the farm owners

\section{Introduction}

The food supply has played an important role in encouraging our normal activities and is an important worldwide industry that has contributed significantly to economic growth and rural development in many nations (Camanzi et al. 2018) and (Mor et al. 2021). Over the previous three decades, India has seen substantial expansion in the dairy sector, with the aim of raising milk output by $9 \%$ per year by 2022 (Ngarava et al. 2020.). The public in developing countries, such as Africa, was concerned about the availability and cost of animal-derived foods, particularly dairy products like milk. The unpredictability of consumer demand for feeds and nutrition and the burden of milk price impulsiveness, resulting in financial issues, unaffordable dairy product prices are the major challenges in Ethiopia (Henchion et al. 2017).

As a base feed source, grass hay and agricultural residues were the most common feed resources at the study location. According to Azage et al. (2013), grass hay and crop leftovers of wheat, barley, teff, and pulse straw are marketed in limited quantities and with poor nutritional values of feeds reduce dairies' production capacity and reproductive potential in Ethiopia

As a result, in order to function successfully, dairy producers must focus on improving their production variables, either by improving the genetic makeup of the dairy cows, or improving the feed and nutrition requirements (Munyeki and Were, 2017) or improved the dairy management practices and dairy farm facility which can minimize the overall production costs and net return increased, with the lowest total feeding costs and efficient labor utilization (Chen et al. 2015). Furthermore, productive efficiency and feed and nutrition could be main area affects dairy farm profitability (Knapp et al. 2014). To reduce the 
complexity of such circumstances, structural equation models (SEM) containing latent and measurable variables to see the direct and total effects of the variables might be systematically investigated (Benjamin et al. 2018)

Studies on dairy farm monitoring and adaptive goals towards dairy feed and nutrition are few, notably in Ethiopia, and/or rely solely on descriptive statistics (Wondatir et al. 2011). These models, however, did not reflect the net influence of factors on response variables and did not separate the causality pathways that link the cause and effect of the variables directly or indirectly affects the dairy management practices (Drews et al. 2018).

Furthermore, there are also challenges on cultural and religious factors, market inaccessibility and lack of modern transportation, poor health and effective extension service, insufficient feeds and nutrition, dairy farm facilities, farm hygiene and poor management practices, lack of appropriate waste disposal system, lack of holistic interventions are all common dairy production constraints in Ethiopia (Mutua 2018). Despite these obstacles, there are some golden opportunities to boost milk demand and, to a lesser extent, milk consumption trends (van der Lee et al. 2020). In order to bridge the gap in the causality relationship as well as to see the direct and indirect effects of the aforementioned measurements on dairy farm management practice, the current study using structural equation model (SEM) could be very important in the study region (Mebrate 2020)

\section{Materials And Methods}

\section{The study location}

\section{Fig. 1. Map of Amhara region}

\section{Sampling techniques}

A face-to-face/in-person/household survey has been used to acquire primary data from 117 stratified selected strata of dairy farm responsible bodies. The sample size was determined using cluster sampling procedures, and its appropriateness was confirmed. In a direct conversation, a well-developed and pretested survey of closed-ended questions that can only be answered by selecting from a limited number of options, usually multiple-choice questions with a single-word answer, "yes" or "no" or a rating scale like "from strongly agree to strongly disagree," was used.

Information was gathered from 15 "kebeles" (the town's smallest administrative unit), comprising individual and cooperative members, as well as university-owned dairy farms, who were nominated to participate in the interview process. In the initial stage, dairy farms stratified as farms having 3-5, 6-10, and more than 10 dairy cows were categorized as small, medium, and large dairy farms (Minten et al. 2021). In the second stage, a total of 864 licensed and legally registered dairy producers were discovered in the three milk shed zones of the Amhara region (small $=457$, medium $=230$, and big $=177$ ). In the sample approach, $11 \%(50), 15 \%$ (35) and $18 \%$ (32) farms of small, medium, and large dairy farms were 
chosen and participated in the study process. The research then involved a total of $117(13.54 \%$ of the population) from the total dairy farm owners, including 113 from individual dairy farms, 2 from cooperatives, and 2 from university research and income-generating dairy farms.

The data gathering took place from 2019 to 2020. The Statistical Package for Social Sciences (SPSS) Ver. 23 and Analysis of Moment Structures (Amos) were used to examine the data (Kline 1998). The questions used to assess dairy performance monitoring (DPM) are based on previous research, and the survey instrument must be validated. The validation is carried out using reliability analysis and the exploratory factor analysis (EFA) method, followed by the confirmatory factor analysis (CFA) process, and finally, structural equation modeling (SEM) is used to track the performance of the dairy farm using the study's outcome variables (Ravindra et al. 2019).

\section{Construct Development and Hypotheses Formulations}

According to a review of the literature, multistage monitoring procedures in the dairy sub-sectors in Ethiopia in general, and the Amhara regional state in particular, have declined significantly. There is limited empirical research on dairy monitoring efficiency and difficulties, as well as the region's dairy production system's performance. The effort demands to the development of an empirical framework to assist policymakers in their evaluation of multi-stage management strategies in dairy production system of the region, the following predictors were recruited for the analysis used to SE model. Educational and training (ED) measured from 1=Reading and Writing, to 5 Degree, health care and extension services: (HES): measured in in Likert scale, from $1=$ strongly disagree to $5=$ strongly agree, dairy farm facility (DFF):measured in Yes/No, hygienic condition and waste management (HWM): measured in in Likert scare, from $1=$ strongly disagree to $5=$ strongly agree, feed and nutrition (FN): measured in in Likert scare, from 1 = strongly disagree to $5=$ strongly agree, mode of transportation (MT): Measured in Yes/No system, reproductive and performances (RP): measured in yes/No, gross revenue (GR): measured as a continuous variable computed daily milk production in litter multiplied by selling price per litter, but it is transformed in to a natural logarithm $(\mathrm{In})$ to make it compatible to the remaining data measurement. After the development the above constructs and based on the conceptual model presented in (Fig. 1); therefore the research has formulated the following the main hypotheses;

$\mathrm{H} 1$ : The better the training and education level (ED, HES) of the farm owner has, the better the dairy farm management (FN, HWM, DFF, and MT), H2: The better the training and educational status (ED, HES) of a farm owner has, the better the productivity of the dairy (RP and GR), H3: if the better the dairy farm management practice has improved (FN, HWM, DFF, and MT) of a farm owner, boosted the productivity of the dairy farm performance (RP and GR), H4: The better if there is rigorous training and education (ED, HES) of a farm owner has, the better the productivity of the dairy (RP and GR) through dairy farm management (FN, HWM, DFF, and MT).

\section{The role of predictor metrics in SEM's dairy management and their impacts}


Promoting sustainable dairy development is critical for meeting the ever-increasing demand of emerging countries' rising populations (Dellmuth and Tallberg, 2015). To bridge up, this demand, yet there is lack the necessary technological, organizational, and institutional capabilities (Guadu and Abebaw, 2016). Farmers' training and education to disseminate improved dairy cattle husbandry practices is an important strategy for increasing dairying's competence and, as a result, adoption (JANETRIX 2019). Many international assistance groups and national governments urge large-scale and ongoing rigorous training for farmers in underdeveloped countries for this reason, but there has been no thorough research on whether these programs are beneficial or not (Seble et al. 2020)

A positive and highly significant relationship between dairy farming training and the adoption of higherquality dairy husbandry practices (Banda et al. 2021). (Misganaw et al. 2016) confirmed that, training and education initiates increased yield and promotes technical efficiency. According to (Shelly M. 2020), training programs have a significant impact on the adoption of new technologies, aid in the achievement of sustainable dairy production, and, as a result, increase gross income and employment in rural areas. On the other hand, a study by emphasizes the value of training, which can help farmers improve their dairy farming skills and generate farm revenues at large (Seble et al. 2020) _

However, for developing countries like Ethiopia, where livestock productivity (meat and milk) is low despite the large cattle population, the increasing human population combined with increasing demand for animal-derived food poses a serious challenge. Feed and nutrition management, both in terms of quality and quantity, is one of the most critical causes of the country's low output level (Asredie and Engdaw, 2015). In Ethiopia, the dairy sub-sector is frequently confronted with feed and nutritional constraints, which are often the most pressing issues and a source of concern in livestock development strategies (Tekeba et al. 2014). According to these sources, during the dry season, ruminants' basic diets consist of fibrous crop residues and pasture, both of which have low nutritional value, making dairy production difficult. Inadequate energy, protein, and mineral intake, on the other hand, are linked to suboptimal dairy cow productivity and reproduction (Sharamo et al. 2021)

An average 35\% deficiency in feed supply can be expected in Ethiopia even during normal years, and this figure may rise to $70 \%$ during drought years (Derara and Bekuma, 2020). This problem is likely to become more serious as a growing human population demands more land for crop production. The main reasons for dairy feed shortages in Ethiopia are therefore related to shrinking grazing lands as a result of expansion of arable cropping; the low contribution of improved forage as livestock feed (0.25\%); and high prices and inaccessibility of concentrates, which further exacerbate the tight situation (Marshall, Salmon et al., 2020)

\section{Dairy health and extension services}

However, in comparison to the great national potential, the dairy sub-contribution sector's to the national economy is insufficient. The extensive incidence of a range of viral and parasite infections, which considerably reduce dairy cattle output and productivity due to sickness, mortality, and market volatility, is the primary reason for this mismatch (Gizaw et al. 2021). In Ethiopia, animal health extension services 
include vaccination, modern (clinical services by professionals and paraprofessionals) and traditional treatments, GIT parasite (deworming) and external parasite (spraying/dipping) controls, disease outbreak investigations and information, herd health advice, and training. Vaccination and contemporary treatments were the most often reported by extension services provider (Bugeza et al. 2017). In general, the quality of animal health care systems is determined by the accessibility, availability, and cost of veterinary services and supplies. Nonetheless, the coverage and access of dairy owners to veterinary services differed significantly across livestock systems, with access being considerably better than other extension services. The most typical problems for health extension services are the relative availability and accessibility of veterinary specialists, basic infrastructure, and other logistics (Gizaw et al. 2019). Most dairy farms' primary purpose is to enhance earnings. Many farmers are inclined to reduce feed expenses because feed accounts for up to half of all costs on a dairy farm, especially when feed prices are high. Feeding for lactation cows, on the other hand, is clearly not a frivolous expense, but rather an investment. Dairy farmers are always looking for feed sources that are less expensive but offer the same results (Baudron et al. 2014)

The high producing dairy cow requires a diet that supplies the nutrient needs for high milk production. Carbohydrates, amino acids, fatty acids, minerals, vitamins, and water are all nutrients required by the lactating dairy cow to meet the demand by the mammary gland to produce milk and milk components. However, in order to develop the cow that will produce a high milk yield, it begins with the nutrition of the calf, lactating cows and heifer (Erickson and Kalscheur, 2020). Dairy cow management interval between drying off and calving, as well as the dry phase, pre-calving period, and calving, is a period of transition. The management, nutrition, and health practices used during the transition period of a cow's lactation cycle will have a significant impact on her productivity and the farm's profitability in the following lactation. (Soberon and Van Amburgh, 2017).

\section{Construction Validity and Reliability}

The latent variables were generated after the hypothesized model displayed in (Fig. 2) was tested and validated to determine how well the model matched the observed data. Feed and nutrition (FN), dairy farm facility (DFF), education level (ED), dairy cow health and extension service (HES), dairy farm hygiene and waste management (HWM), reproductive performance (RP), and gross revenue are the latent variables in the model (GR). Each of the latent variables was measured in the model using a minimum of four and a maximum of seven observed variables. Analyzing Moment Structures was used to run and evaluate the model (AMOS-ver. 21 program). In (Figure1) it estimates were made using the maximum likelihood estimate over other estimation approaches (Kline 2011). To examine the model's validity in terms of both model fit (MF) and Construct Validity (CV), the model was evaluated using (Hair, Halle et al. 2006). In (Table 1) the model's summary results, this included the Factor loading (FL) and Standardized $(\mathrm{SFL})$, the mean $(\bar{Y})$, standard deviation (SD) of each latent variable, Cronbach-alpha (a), chi-square (2), pvalue, the Tucker-Lewis coefficient (TLI), the comparative fit index (CFI), and Root Mean Square Error of Approximation (RMSEA) 
It is a measure of the internal consistency coefficient, or how closely related a collection of items are as a group, and it discloses the equivalence, homogeneity, and correlation of the statements to assess scale reliability. As it is presented below in (Table 1), the result showed that all the latent variables have exhibited a value 0.80 or above which is acceptable (Mor, Bhardwaj et al. 2019). However, during the test one of the latent variables, Reproductive Performance (RP), has exhibited low value $(a=0.310)$ and when two of the items were deleted the a value was improved to $a=0.842$. Initially its Cronbach's alpha value was low as 0.684 , but after revising and one of the items was discarded items with low correlation, the reliability of the Cronbach's become improved with the better value to $a=0.801$. Furthermore, for the sake of additional testing, the average variance extracted (AVE) and Construct Reliabilities (CR) were computed and given in the same table. All of the latent variables have CR values greater than the desirable $\geq 0.5$ limit. Moreover, all of the latent variables have an AVE greater than the cutoff value of 0.5 . Both of these tests showed that the model is well fitted to the data.

\section{Table 1. Exploratory Factor Analysis (EFA) of dairy farm monitoring practices in SEM analysis}


1 Measurable variables

$\mathrm{FL}^{*} \quad \mathrm{SFL} \quad \mathrm{AVE} \quad \mathrm{CR}$

SD.

\begin{tabular}{|c|c|c|c|c|c|c|c|c|}
\hline \multirow[b]{2}{*}{ water } & \multicolumn{6}{|c|}{$\begin{array}{l}\text { Latent } \\
\text { Variables }\end{array}$} & \multicolumn{2}{|l|}{$\bar{y}$} \\
\hline & $<-$ & DFF & 1.000 & 0.884 & 0.832 & 0.972 & 1.581 & 0.414 \\
\hline Solar & $<-$ & DFF & 0.866 & 0.765 & & & & \\
\hline ECC & $\begin{array}{l}<- \\
-\end{array}$ & DFF & 0.835 & 0.738 & & & & \\
\hline Toilet & $<-$ & DFF & 0.976 & 0.857 & & & & \\
\hline Iron roof & $\begin{array}{l}<- \\
-\end{array}$ & DFF & 0.910 & 0.816 & & & & \\
\hline Brick Wall & $<-$ & DFF & 0.898 & 0.793 & & & & \\
\hline Filed Floor & $<-$ & DFF & 0.887 & 0.772 & & & & \\
\hline
\end{tabular}

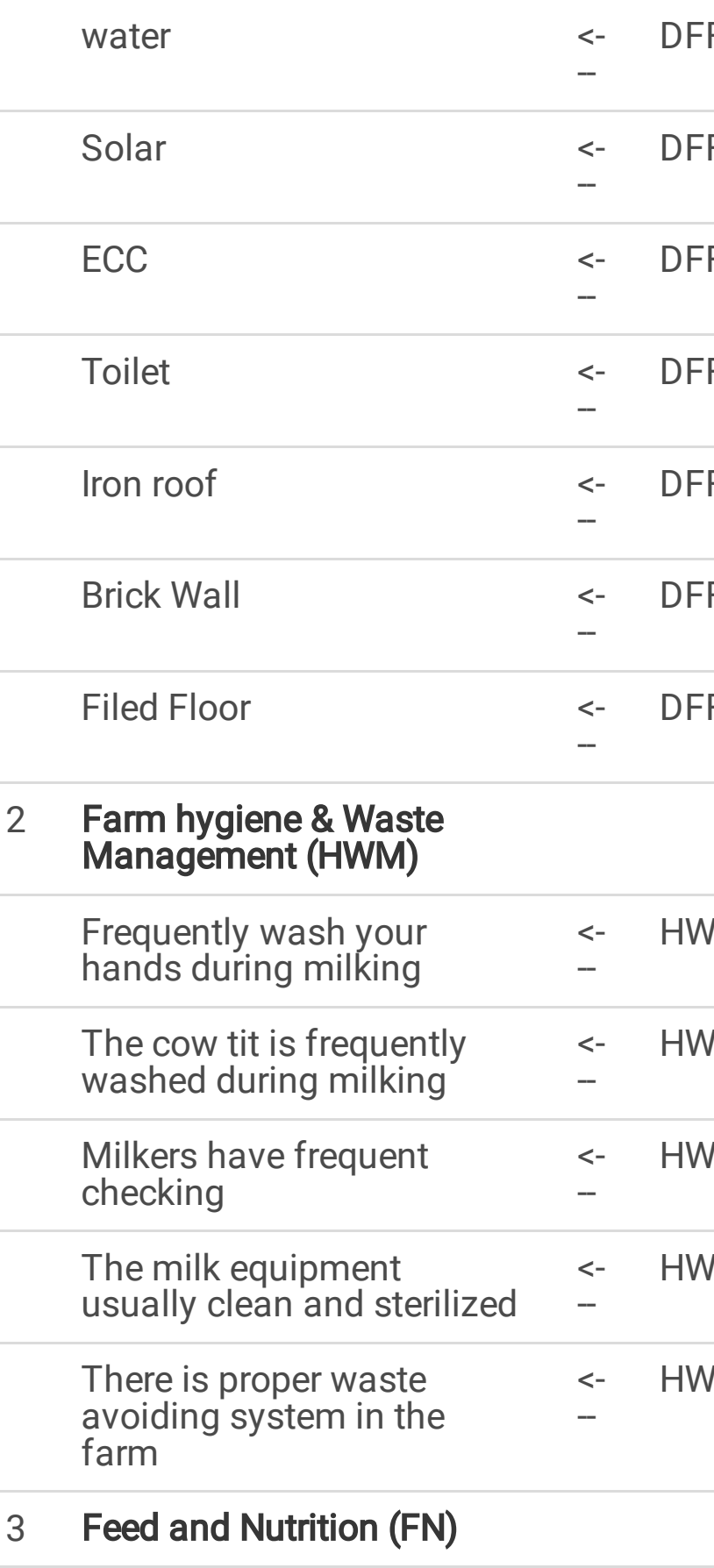

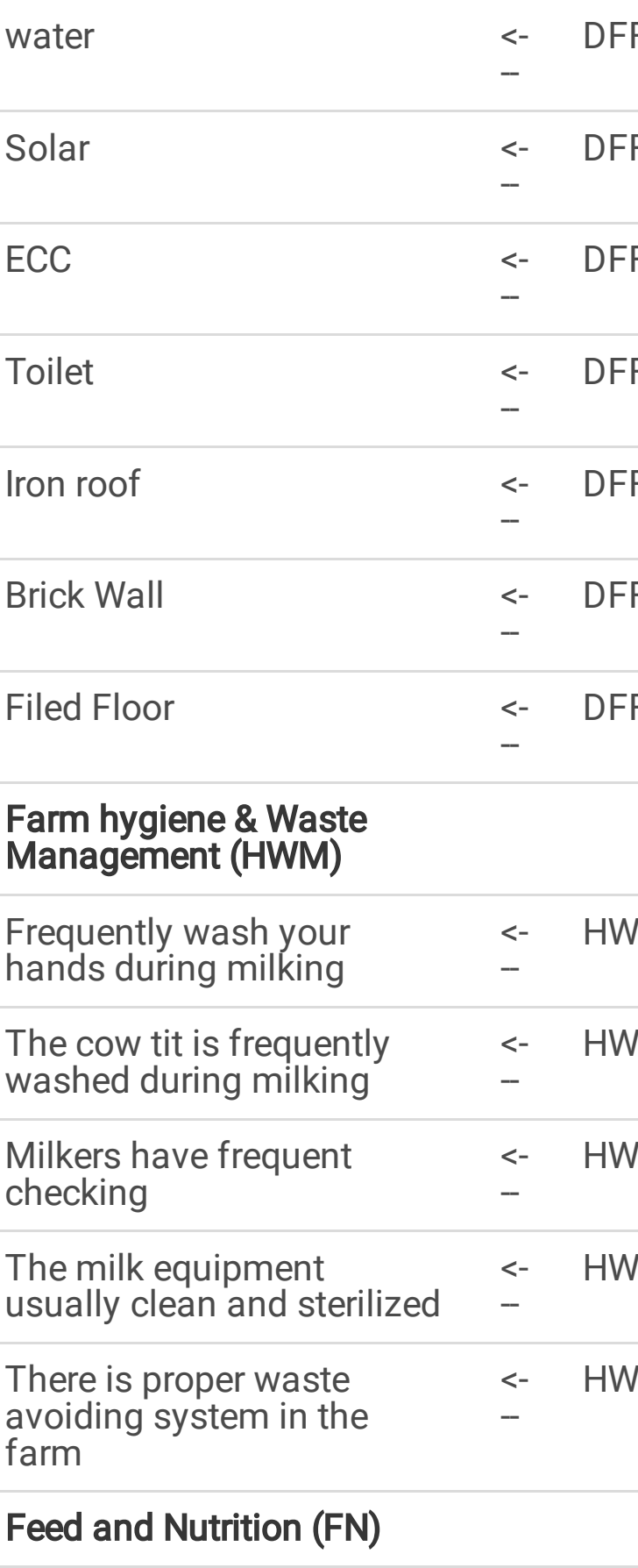

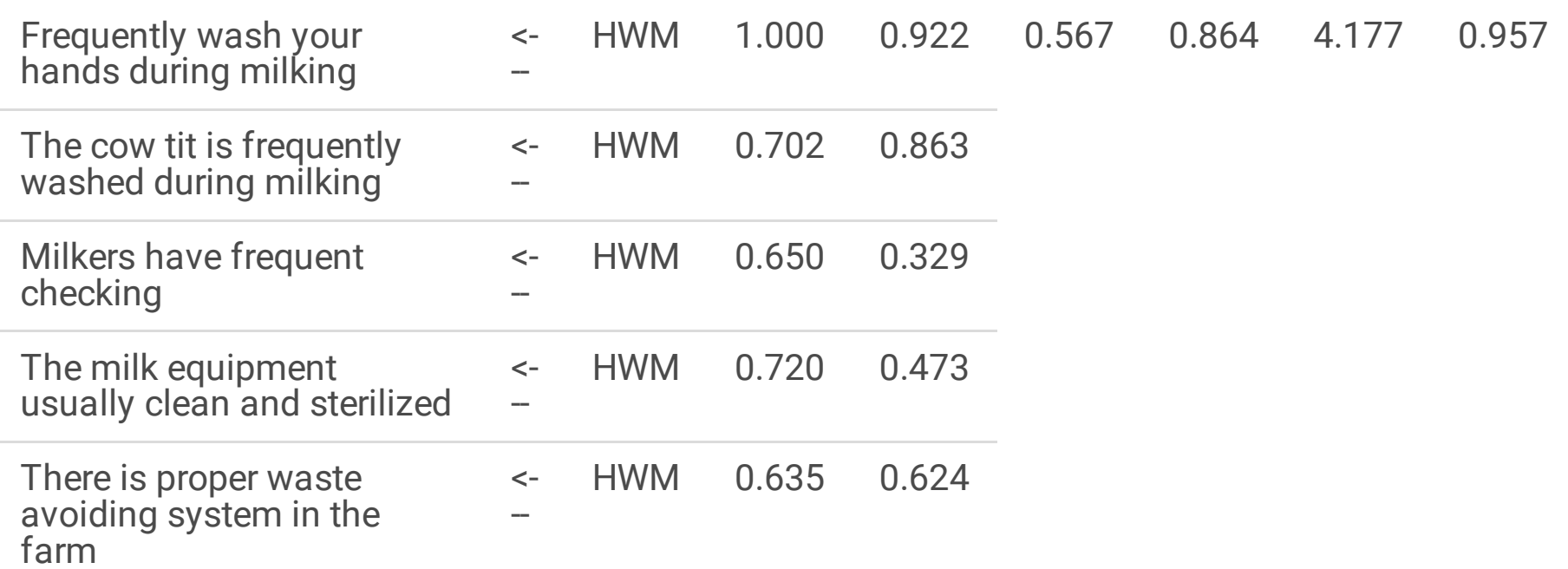

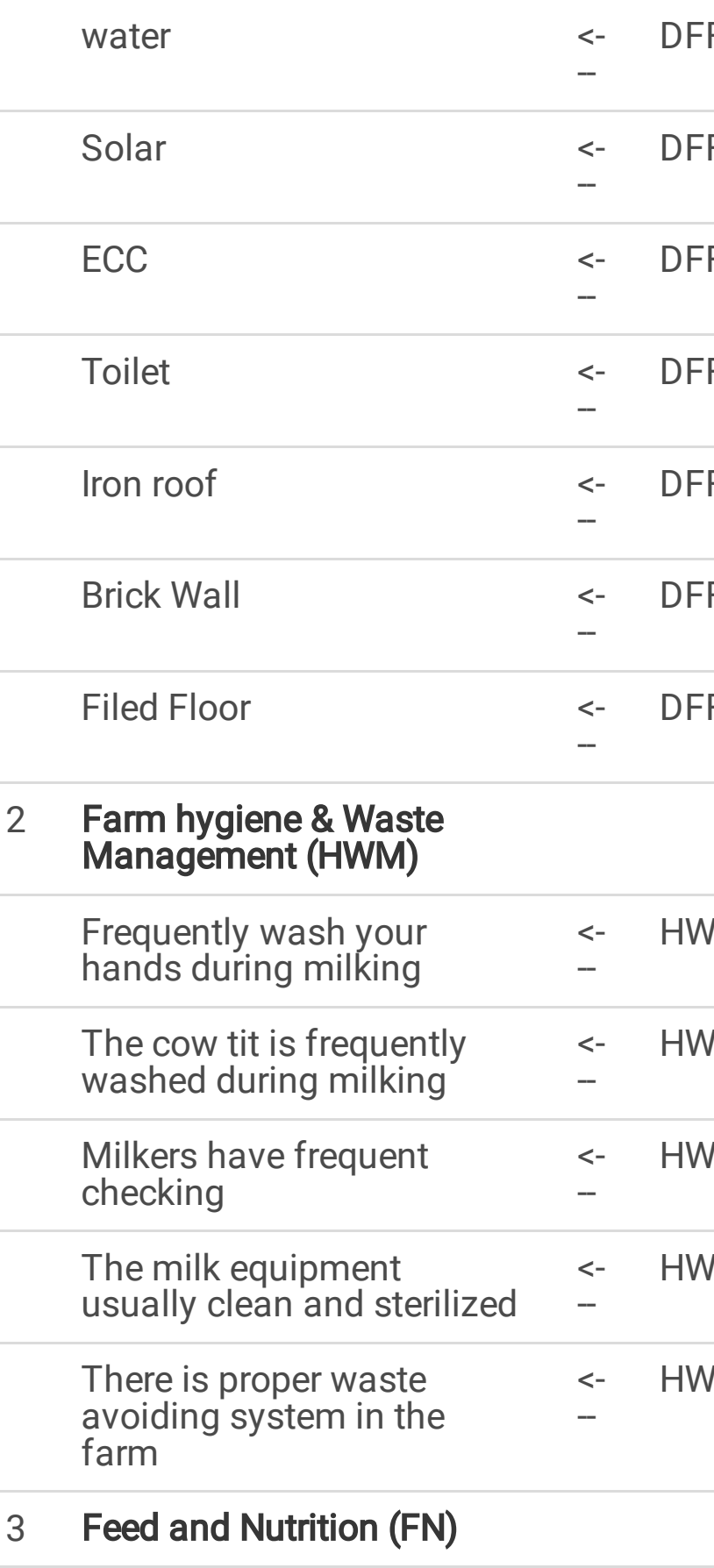

$\begin{array}{llllllll}<- & \text { FN } & 1.000 & 0.799 & 0.675 & 0.865 & 4.785 & 0.958\end{array}$

frequently used Cope residue

$<-$
-

frequently used

$\begin{array}{llll}<- & \text { FN } & 0.048 & 0.036\end{array}$

commercially formulated feed

frequently feed industrial $\quad<-$ FN $\quad 0.866 \quad 0.842$ 
feed

4 Reproductive Performance (RP)

Heat Trained

$\begin{array}{llll}<- & \text { RP } & 1.000 & 0.965\end{array}$

0.73

0.912

1.888

0.2704

Al Record

$\begin{array}{llll}<- & \text { RP } & 0.991 & 0.793\end{array}$

Al practice

$\begin{array}{llll}<- & \text { RP } & 0.785 & 0.694\end{array}$

Al Pay

$\begin{array}{llll}<- & \text { RP } & 0.568 & 0.577\end{array}$

5 Health and Extension Service

(HES)

The extensive services

$\begin{array}{llllllll}<- & \text { HES } & 1.000 & 0.954 & 0.549 & 0.875 & 4.045 & 0.995\end{array}$

supported you

$-$

Frequently consulted the veter.

$<-\quad$ HES $\quad 0.710 \quad 0.874$

The vet clinic provide

$-$

appropriate services

$\begin{array}{llll}<- & \text { HES } & 0.824 & 0.817\end{array}$

$-$

The animals are regularly vaccinated

$<-\quad$ HES $\quad 0.702 \quad 0.879$

The vaccine service is

heaper

$<-\quad$ HES $\quad 0.578 \quad 0.672$

The extension service provides

$\begin{array}{llll}<- & \text { HES } & 0.533 & 0.541\end{array}$

6 Mode of Transport (MT)

$\begin{array}{lllllllll}\text { transport by Ox Cart } & <- & \text { MT } & 1.000 & 0.843 & 0.645 & 0.872 & 1.858 & 0.806\end{array}$

Transport by foot

$<-\quad$ MT $\quad 0.966 \quad 0.948$

transport by bicycle

$<-\quad$ MT $\quad 0.570 \quad 0.643$

Transport by Vehicle

$\begin{array}{llll}\text { - } & \text { MT } & 0.568 & 0.505\end{array}$

\section{Continuous Variable}

7 Farm owners education in years

ED

8 Gross Revenue (LN

GR

Transformed) 
1 Measurable variables

$a(\dot{a}) \quad \chi^{2} \quad$ TLI $\quad$ CFI $\quad$ RM

Latent

Variables

(p-Val.)

SEA

water

$<-\quad$ DFF

0.927

83.53

0.77

0.852

0.242

$-$

$(0.000)$

Solar

$<-\quad$ DFF

$-$

ECC

$<-\quad$ DFF

$-$

Toilet

$<-\quad$ DFF

$-$

Iron roof

$<-\quad$ DFF

Brick Wall

$<-\quad$ DFF

$-$

Filed Floor

$<-\quad$ DFF

\section{Farm hygiene \& Waste Management} (HWM)

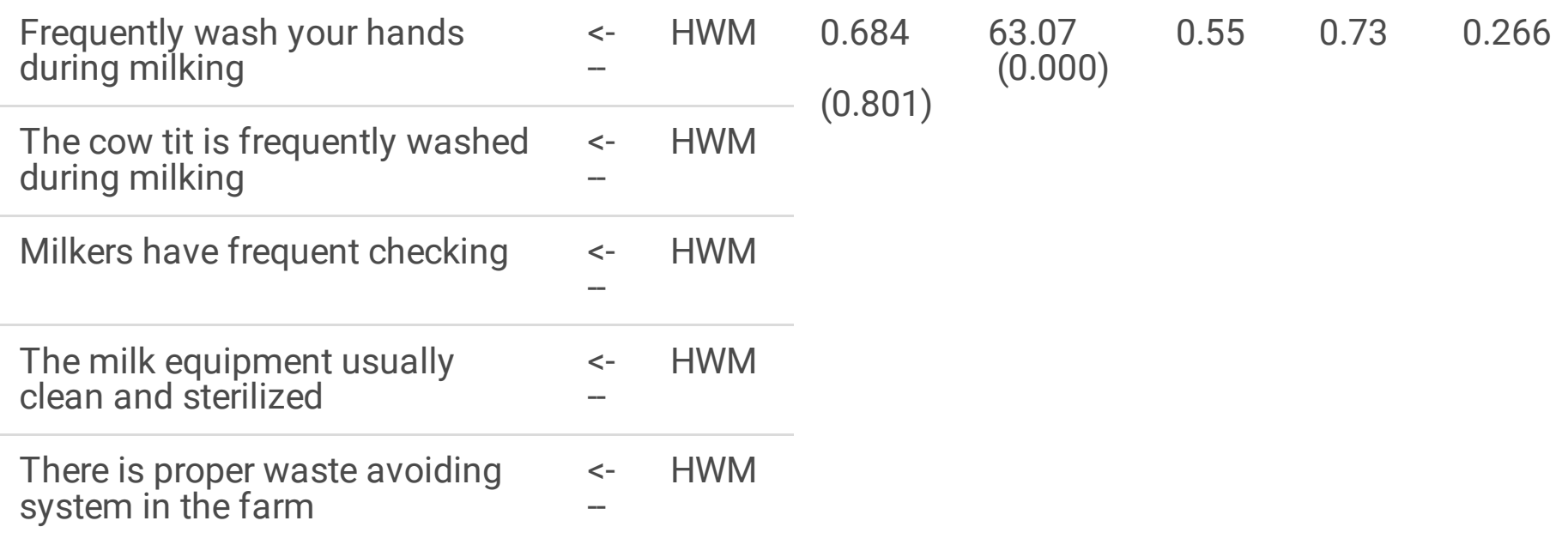

\section{Feed and Nutrition (FN)}

frequently used Green feed

$\begin{array}{lllllll}<- & \text { FN } & 0.654 & \begin{array}{c}17.158 \\ (0.000)\end{array} & 0.747 & 0.916 & 0.299\end{array}$

frequently used Cope residue $\quad<-F N$

frequently used commercially $\quad<-F N$

formulated feed

frequently feed industrial feed $<-F N$ 
4 Reproductive Performance (RP)

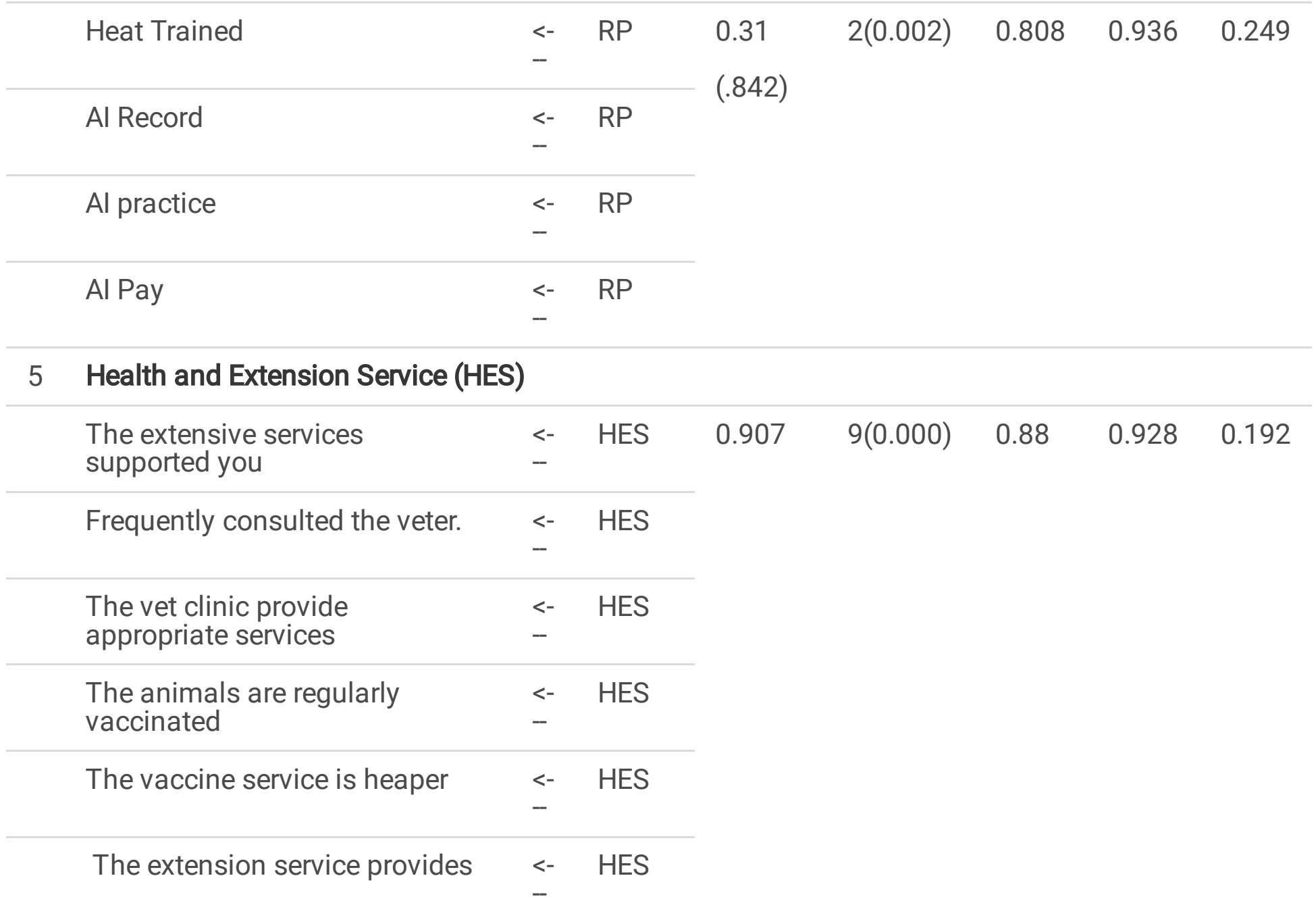

6 Mode of Transport (MT)

$\begin{array}{llllllll}\text { transport by Ox Cart } & <- & \text { MT } & 0.815 & 2.00 & 0.956 & 0.985 & 0.112\end{array}$

Transport by foot $\quad<-M T$

transport by bicycle $\quad<$ MT

Transport by Vehicle $\quad<-$ MT

\section{Continuous Variable}

7 Farm owners education in years $\quad$ ED

8 Gross Revenue (LN GR Transformed)

Key: *=all the Factor Loading (FL)has shown strong statistical significance at $p<0.01, S F L=S t a n d a r d i z e d$ Factor Loading, AVE= Average Variance Extracted, $C R=$ Construct reliability, $\overline{\mathbf{Y}}=$ Mean, $S \mathrm{~S}=\mathrm{Standard}$ Deviation, $a(a)=$ Cronbach Alpha ( $a$ if item discarded), $\chi^{2}(p-v a l u e)=$ Chi-square $(P-V a l u e), T L I=$ Tucker- 


\section{Lewis coefficient index, GFI= goodness of fit index, CFI= Comparative Fit Index,RMSAE= Root Mean Square Approximation Error. \\ Results}

Hence, the directly observed and similar to a true score that is not directly observed, and there is no degree of random measurement error since the observed score does not completely match the true score values. As a result indicated in(Fig.3)below depicts that, arrows in the model connects each latent variables with a total of 30 measurement statement labels that are linked to latent variables and can be used to estimate their relationship of the latent variables. The conceptual model was revised as shown in (Fig. 3) which recurring enhancements and modifications of the variables. The final run was done based on the model's findings to determine the direct, indirect, and total effects of the various structures. The chi-square analysis value for the variables was 123.408 with four degrees of freedom (df) and a p-value of 0.0723 . As a result, the entire model was deemed statistically significant, suggesting that the data was correctly fitted to the model $(P>0.05)$, demonstrating that the data supported the proposed model's distributional assumptions and that the model is accurate. The research model is tested using the path analysis to describe the directed dependencies among a set of variables and the findings of the results indicated that the data fits the model reasonably well with goodness of fit index (GFI) of 0.87, confirmatory fit index (CFI) of 0.925 , TLI of 0.479 , and root mean square of approximate error (RMSAE) of 0.09 , but then again low total loading index and Tucker-Lewis coefficient index (TLI) value.

A structural equation model was developed for dairy farm monitoring approaches in milk production. The circles indicate latent variables, whereas the rectangles represent measurement variables. Arrows between circles indicate relationships between latent variables (path coefficients analysis). Arrows connecting circles and rectangles indicate the indicator reliabilities of the various measurement variables. More general explanations and a bigger framework of a structural equation model can be found in (Fig. 1). In (Table 1) provides an overview of the latent variables and their associated measurement variables.

In (Table 2) shown below, the model result, which shows that the relationship between construct reliabilities was statistically and significantly significant $(p<0.01)$, with a positive relationship between the variables with values of $(\rho=0.728)$, hygienic condition and waste management techniques (HWM) of the dairy farm becomes $(\rho=0.641)$, feed and nutrition $(F N)$ of the cows also showed $(\rho=0.657)$, and mode of transportation (MT) employed to transfer the dairy products to market place indicates as ( $\rho=$ 0.372). The other variables of the findings revealed that the level of education (ED) has a positively linked and significant association with that of dairy farm facilities (DFF) exist in the respective dairy farms. Similarly, the availability and accessibility of health and extension services (HES) in each dairy farm's had a constructive and significantly strong relationship with dairy farm facilities (DFF) $(\rho=0.961)$, farm hygiene and waste management (HWM) had a value of $(\rho=0.988)$, feed and nutrition (FN) had a value of $(\rho=0.914)$, and mode of transport (MT) had a value of $(\rho=0.852)$. Generally all of this suggests that there is a good and challenging interaction effects between farm management and training and education on (HES, ED) (DFF, FN, HWM, MT). 
Additionally, the model revealed that the level of education (ED) has also a positive and statistically significant relationship with the reproduction performance (RP) of the dairy cows, with a probability value of ( $\rho=0.337)$ and the gross revenue (GR) of the farm showed as $(\rho=0.849)$; in addition the health and extension serveries (HES) has a positive and statistically significant relationship with $\operatorname{RP}(\rho=0.799)$ and GR ( $\rho=0.943)$; which indicates that there is a positive and a strong numerical interpretation and significant connotation between farm productivity and training and education on (HES and ED) (RP and $\mathrm{GR})$.

\section{Table 2. Correlations Analysis ( $p$ ) among constructs}

\begin{tabular}{|c|c|c|c|c|c|c|c|}
\hline & ED & GR & DFF & HES & HWM & $\mathrm{FN}$ & $\mathrm{RP}$ \\
\hline GR & $.849^{\star \star}$ & & & & & & \\
\hline DFF & $.728^{\star \star}$ & $.934^{\star \star}$ & & & & & \\
\hline HES & $.682^{\star \star}$ & $.943^{\star \star}$ & $.961^{\star \star}$ & & & & \\
\hline HWM & $.641^{* *}$ & $.921^{* \star}$ & $.961^{* \star}$ & $.988^{* *}$ & & & \\
\hline FN & $.675^{\star \star}$ & $.906^{\star \star}$ & $.824^{\star \star}$ & $.914^{\star \star}$ & $.899^{\star \star}$ & & \\
\hline $\mathrm{RP}$ & $.337^{\star \star}$ & $.690^{\star \star}$ & $.641^{* *}$ & $.799^{\star *}$ & $.798^{\star *}$ & $.842^{\star *}$ & \\
\hline MT & $.379 * \star$ & $.738^{\star *}$ & $.707^{\star \star}$ & $.852^{\star \star}$ & $.851^{\star *}$ & $.880 * \star$ & $.970 * *$ \\
\hline
\end{tabular}

The other important variables was reproductive performance (RP) of a dairy farm which is also strongly linked with the farm management practices such as FN $(\rho=0.842), \operatorname{DFF}(\rho=0.641), \operatorname{HWM}(\rho=0.798)$, and MT $(\rho=0.970)$, through a represented significant relationship. Farm gross revenue (RG) shows a positive, strong, and statistically significant association with FN with the value of $(\rho=0.906)$, DFF $(\rho=$ $0.934), \operatorname{HWM}(\rho=0.921)$, and MT $(\rho=0.738)$. Therefore, all of these findings, suggests that farm management practices have a strong and positive relationship with dairy farm productivity of the region.

\section{Table 3.The Regression Weight Analysis ( $\beta$ ) of the Structural Equation Modeling (SEM)}


Direct Effects $\quad$ Estimate $(\beta) \quad$ S.E. $\quad$ P-Value. $\mathrm{R}^{2}$

\begin{tabular}{|c|c|c|c|c|c|c|}
\hline DFF & $<-$ & HES & 0.362 & 0.016 & $\star \star \star$ & \multirow[t]{2}{*}{0.934 (DFF) } \\
\hline DFF & $<-$ & ED & 0.044 & 0.012 & $\star \star \star$ & \\
\hline FN & $<-$ & HES & 0.817 & 0.057 & $\star \star \star *$ & \multirow[t]{2}{*}{$0.840(\mathrm{FN})$} \\
\hline FN & $<-$ & ED & 0.072 & 0.044 & 0.107 & \\
\hline MT & $<-$ & HES & 0.313 & 0.019 & 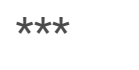 & \multirow[t]{2}{*}{$0.802(\mathrm{MT})$} \\
\hline MT & $<-$ & ED & -0.083 & 0.014 & 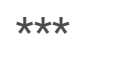 & \\
\hline HWM & $<-$ & ED & -0.081 & 0.016 & $\star \star \star *$ & \multirow[t]{3}{*}{ 0.892(HWM) } \\
\hline HWM & $<-$ & HES & 0.702 & 0.049 & $\star \star \star$ & \\
\hline HWM & $<-$ & DFF & 0.798 & 0.124 & $\star \star \star$ & \\
\hline RP & $<-$ & HES & 0.330 & 0.063 & $\star \star \star$ & \multirow[t]{5}{*}{$0.885(\mathrm{RP})$} \\
\hline RP & $<-$ & ED & -0.038 & 0.013 & 0.004 & \\
\hline RP & $<-$ & FN & 0.083 & 0.027 & 0.002 & \\
\hline RP & $<-$ & DFF & -0.910 & 0.111 & $\star * *$ & \\
\hline RP & $<-$ & HWM & 0.222 & 0.080 & 0.006 & \\
\hline GR & $<-$ & HES & 0.197 & 0.117 & 0.093 & \multirow{7}{*}{$0.975(\mathrm{GR})$} \\
\hline GR & $<-$ & ED & 0.167 & 0.017 & $\star \star \star *$ & \\
\hline GR & $<-$ & $\mathrm{FN}$ & 0.150 & 0.033 & $\star \star \star$ & \\
\hline GR & $<-$ & HWM & -0.070 & 0.095 & 0.462 & \\
\hline GR & $<-$ & MT & -0.111 & 0.132 & 0.401 & \\
\hline GR & $<-$ & $\mathrm{RB}$ & 0.210 & 0.124 & 0.089 & \\
\hline GR & $<-$ & DFF & 0.448 & 0.205 & 0.029 & \\
\hline
\end{tabular}

In general, the regression values that qualify as a "good" R-Squared value will vary depending on the situation, with the value becoming 0.5 in the weakest case and greater than 0.5 in the strongest case. The best regression value reading criteria, on the other hand, could be substantially higher, such as 0.9 or advanced. R-Squared values above 0.7 indicate a high level of correlation, whereas R-Squared values below 0.4 indicate a low level of correlation. As a result, the regression values estimated that the predictors of dairy farm facilities (DFF), feed and nutrition (FN), dairy farm hygiene and waste management (HWM), mode of transport (MT), reproduction performance (RP), and gross revenue (GR) 
explained 93.40 percent, 84.00 percent, 80.20 percent, 89.20 percent, 88.50 percent, and 97.50 percent, respectively, of the variance.

The findings in the result (Table 3) indicated that except for the path leading from educational level (ED) to FN ( $\beta=0.072$ ), all the path coefficients leading from training and education (ED and HES) showed good predictors of the farm management system, that was, ED to DFF ( $\beta=0.044)$, ED to HWM ( $\beta=$ $-0.081)$, ED to MT $(\beta=-0.083)$, HES to FN $(\beta=0.817)$, HES to DFF $(\beta=0.362)$, HES to HWM $(\beta=0.702)$, and HES to MT ( $\beta=0.313$ ) were all statistically significant predictors partially supporting the hypothesis one $(\mathrm{H} 1)$ that states "The better the training and education (ED, HES) of the farm owner had showed, the better the dairy farm management practices of (FN, HWM, DFF, and MT)". Though, the negative and statistically significant prediction of ED to HWM and that of MT was indicated an unexpected result.

Furthermore, training and education (HES and ED) were statistically significant predictors of agricultural productivity (PR and GR) based on HES to GR (= 0.197); they partially support hypothesis two $(\mathrm{H} 2)$ : The higher the dairy (RP and GR) production, the more training and education a farm owner has gotten (ED, $\mathrm{HES})$. On the other hand, the negative regression coefficient $(=-0.038)$ discovered between $E D$ and $R P$, on the other hand, is unexpected. The third hypothesis is that "the greater the dairy farm owner's (FN, HWM, DFF, and MT) management improvement, the higher the dairy farm's production to the (RP and GR)" of the research data presented above (Table 3$)$. With the exception of the paths leading to FN to RP $(=0.083)$ and DFF to GR (= 0.448), which were positive and statistically significant predictors, additional farm management methods are not predictors of the RP and GR. On the other hand, the negative associations between HWM and GR, MT and GR, and DFF and RP, on the other hand, were unexpected and almost failed to support hypothesis three $(\mathrm{H} 3)$.

\section{Table 4. Indirect and Total Effects of the SE model}




\section{Indirect and total Effect Estimate $(\beta) \quad$ Lower Upper P-Value}

Indirect

\begin{tabular}{lllll}
\hline HES_FN_RP & 0.068 & 0.000 & 0.134 & 0.048 \\
\hline HES_HWM_RP & 0.156 & 0.073 & 0.252 & 0.002 \\
\hline HES_DFF_HWM_RP & 0.064 & 0.019 & 0.142 & 0.003 \\
\hline ED_FN_RP & 0.006 & 0.000 & 0.020 & 0.060 \\
\hline ED_HWM_RP & -0.018 & -0.038 & -0.007 & 0.002 \\
\hline ED_DFF_HWM_RP & 0.008 & 0.002 & 0.021 & 0.001 \\
\hline ED_DFF_RP & -0.040 & -0.072 & -0.017 & 0.001 \\
\hline HES_DFF_GR & 0.162 & 0.067 & 0.296 & 0.011 \\
\hline HES_DFF HWM_RP_GR & 0.013 & 0.000 & 0.044 & 0.055 \\
\hline HES_MT_GR & -0.035 & -0.181 & 0.041 & 0.431 \\
\hline HES_HWM_GR & -0.049 & -0.177 & 0.045 & 0.207 \\
\hline ED_FN_GR & 0.011 & -0.002 & 0.025 & 0.064 \\
\hline ED_DFF_HWM_RP_GR & 0.002 & 0.000 & 0.007 & 0.037 \\
\hline ED_DFF_GR & 0.020 & 0.008 & 0.038 & 0.003 \\
\hline ED_MT_GR & 0.009 & -0.011 & 0.047 & 0.443
\end{tabular}

Total Indirect Effects

\begin{tabular}{lcccc} 
TIE_HES_RP & 0.288 & 0.141 & 0.439 & 0.004 \\
\hline TIE_ED_RP & -0.052 & -0.103 & -0.013 & 0.008 \\
\hline TIE_HES_GR & -0.120 & -0.360 & 0.074 & 0.208 \\
\hline TIE_ED_GR & 0.041 & 0.013 & 0.076 & 0.011
\end{tabular}

\section{Total Effects}

\begin{tabular}{lcccc}
\hline TE_HES_RP & 0.618 & 0.446 & 0.731 & 0.002 \\
\hline TE_HES_GR & 0.077 & -0.164 & 0.295 & 0.361 \\
\hline TE_ED_RP & -0.090 & -0.123 & -0.058 & 0.002 \\
\hline TE_ED_GR & 0.209 & 0.172 & 0.258 & 0.002
\end{tabular}

After extra investigation, the model's indirect and total effect predictors of training and education (HES and ED) were further evaluated. In this regard, the total indirect effect in table 3 showed that all channels of health and extension services (HES) through farm management (DFF, FN, HWM, and MT), as well as 
the quantity of education (ED) the farm owner has through farm management, were investigated (DFF, FN, HWM, and MT). According to (Table 4); all of the alternate pathways from HES to RP $(\beta=0.288)$ and from ED to GR $(\beta=0.041)$ are statistically and positively significant. All of the pathways from HES to GR $(\beta=-0.120)$ are statistically significant and unexpectedly negative. All of the lines from ED to RP ( $\beta$ $=-0.052$ ) are unexpectedly negative, but not significant. Hypothesis four $(\mathrm{H} 4)$ was partially supported: "The better the training and education (ED, HES), the better the dairy's productivity (RP and GR) through dairy farm management (FN, HWM, DFF, and MT)." In addition, the overall effects of the model revealed that education (ED) was a stronger predictor of GR than HES, whereas HES was a greater predictor of PR. Nonetheless, HES is not a predictor of GR, while ED is a statistically significant predictor of PR in a negative way, which the researchers did not expect.

\section{Discussion}

All predictor variables' estimated Factor Loadings $(\mathrm{FL})$ produced as a regression weight in the analysis of moment of structure (AMOS) were statistically strongly significant $(P<0.01)$, and the regression weight was found to be above 0.50 , implying convergent validity (Ali et al. 2018). According to Yu and Xie (2012); the standardized regression weights be 0.50 or higher, preferably 0.7 or higher. They also suggested that cutoff values such as RMSEA 0.06, TLI >0.95, CFI > 0.95, and CFI >0.95 were appropriate for categorical outcomes. With the exception of the built MT, the TLI value of the majority of the constructs is less than 0.95. With regard to TLI, except DFF and HWM, it exhibits a good fit with TLI value greater than 0.9. HWM has the lower TLI which 0.55. Furthermore, the farm management practices implemented in the dairy farm such as (FN, DFF, HWM and MT) required strongly promoted the farm productivity (PR and GR)these findings are highly relevant on the findings of (Soteriades, Stott et al., 2016). Furthermore, training and education for dairy farm owners, such as health and extension services (HES) and educational (ED), are both good predictors of farm management systems (HWM, DFF, MT) and farm production (RP and GR), according to the data (Soteriades et al. 2016). Furthermore, farm management methods (HWM, FN, and DFF) are good predictors of one of the farm's production (RP), which supports the findings (Drews et al. 2018). As shown in the graph above, there was a highly significant difference $(P<0.001)$ in the availability of dairy farm infrastructure, dairy cow health and extension service delivery, farm hygienic condition and waste management practices, and farm reproductive performance (Table 4). The model analysis revealed a substantial difference $(P<0.01)$ between reproductive performance and artificial insemination services, as well as diet and nutrition requirements, as well as dairy cow health and extension services. These findings are consistent with the conclusions of a previous study. Both (Diro et al. 2019) and (Mor et al. 2021) reached similar conclusions.

\section{Conclusion}

The educational levels of dairy farm operators were also demonstrated to have a significant impact on farm hygiene and waste management procedures, and the relationship between the mode of dairy 
product transportation was also similarly affected the dairy management practice. The dairy cow health status and extension service providers also presented substantial transformation on the management of dairy farm hygienic conditions and farm waste controlling strategies in the study areas, whereas the feed and nutritional requirements of the dairy farm had a highly impacted with the educational levels of the dairy actors. As a consequence of the this findings, the dairy farm management practices mainly focusing on (FN, DFF, HWM, and MT) as well as farm productivity and reproductive enactments (RP and GR) of the dairy farm were positively and significantly influenced by access to training and education level of the dairying.

\section{Declarations}

Funding: Since, this research is my own PhD dissertation work, I did not received any support or financial grant for this research.

Computing of Interest: The authors have not any interests that are directly or indirectly affect the work and publication of this manuscript

Ethics approval: Note applicable for this research

Consent to participate: Note applicable for this research

Consent to publish: Note applicable for this research

Availability of data and material: All the research the research data generated during and/or analyzed during the current study are available in my PC and when it is necessary and requested to present, it would be ready.

Code availability: Note applicable for this research

Authors Contribution: The research conception and design, material preparation, data collection, analysis and write up of the manuscript were performed by Malede Birhan, Dr. Yeshambe Mekuriaw, Dr. Asaminew Tassew and Dr. Firew Tegegne, since these are my academic advisors they were participated for correcting and comments from the first draft of the manuscript to the final version of the manuscript until approval of the final paper

\section{ACKNOWLEDGEMENT}

The expressed gratitude to the dairy proprietors and cooperative dairy employees who accept and engaged in this research activity of the milk shed areas of Amhara region. The technical support of the College of agriculture and environmental sciences personnel, as well as animal biotechnology laboratory workers, is gratefully thanked.

\section{References}


1. Ali, F., S. M. Rasoolimanesh, M. Sarstedt, C. M. Ringle and Ryu K., 2018. "An assessment of the use of partial least squares structural equation modeling (PLS-SEM) in hospitality research." International Journal of Contemporary Hospitality Management. Vol. 30 No. 1, pp. 514-538. https://doi.org/10.1108/IJCHM-10-2016-0568

2. Asredie, T. and Engdaw T. A., 2015. "Antimicrobial residues in cow milk and its public health significance." World J Dairy Food Sci 10(2): 147-153. DOI: 10.5829/idosi.wjdfs.2015.10.2.96244.

3. Banda, L. J., D. Chiumia, T. N. Gondwe and Gondwe S. R., 2021. "Smallholder dairy farming contributes to household resilience, food, and nutrition security besides income in rural households." Animal Frontiers 11(2): 41-46. https://doi.org/10.1093/af/vfab009

4. Baudron, F., M. Jaleta, O. Okitoi and Tegegn A., 2014. "Conservation agriculture in African mixed croplivestock systems: expanding the niche." Agriculture, Ecosystems \& Environment 187: 171-182. https://doi.org/10.1016/j.agee.2013.08.020

5. Benjamin, D. J., J. O. Berger, M. Johannesson, B. A. Nosek, E.-J. Wagenmakers, R. Berk, K. A. Bollen, B. Brembs, L. Brown and Camerer C., 2018. "Redefine statistical significance." Nature human behaviour 2(1): 6-10. https://doi.org/10.1038/s41562-017-0189-z

6. Bugeza, J., C. Kankya, J. Muleme, A. Akandinda, J. Sserugga, N. Nantima, E. Okori and T. Odoch, 2017. "Participatory evaluation of delivery of animal health care services by community animal health workers in Karamoja region of Uganda." PloS one 12(6): e0179110.

https://doi.org/10.1371/journal.pone.0179110

7. Camanzi, L., Arba, C. Rota, Zanasi and Malorgio G., 2018. "A structural equation modeling analysis of relational governance and economic performance in agri-food supply chains: evidence from the dairy sheep industry in Sardinia (Italy)." Agricultural and Food Economics 6(1).

https://doi.org/10.1186/s40100-018-0099-z

8. Chen, J. L., D. J. Margolis, A. Stankov, L. T. Sumanovski, B. L. Schneider and Helmchen F., 2015. "Pathway-specific reorganization of projection neurons in somatosensory cortex during learning." Nature Neuroscience 18(8): 1101-1108.https://doi.org/10.1038/nn.4046

9. Cubas, M., A. Lucquin, H. K. Robson, A. C. Colonese, P. Arias, B. Aubry, C. Billard, D. Jan, M. Diniz and Fernandes R., 2020. "Latitudinal gradient in dairy production with the introduction of farming in Atlantic Europe." Nature communications 11(1): 1-9. https://doi.org/10.1038/s41467-020-15907-4

10. Dellmuth, L. M. and Tallberg J., 2015. "The social legitimacy of international organisations: Interest representation, institutional performance, and confidence extrapolation in the United Nations." Review of International Studies 41(3): 451-475. https://doi.org/10.1017/S0260210514000230

11. Derara, A. and Bekuma A., 2020. "Study on Livestock Feed Resources, Biomass Production, Feeding System and Constraints of Livestock Production in Relation to Feeds in Weliso District, South West Shoa Zone, Ethiopia." Op Acc J Bio Sci \& Res 4(1). doi:10.46718/JBGSR.2020.05.000113

12. Drews, J., I. Czycholl, W. Junge and Krieter J., 2018. "An evaluation of efficiency in dairy production using structural equation modelling." The Journal of Agricultural Science 156(8): 996-1004. https://doi.org/10.1017/S0021859618001041 
13. Erickson, P. S. and Kalscheur K. F., 2020. Nutrition and feeding of dairy cattle. Animal Agriculture, Elsevier: 157-180. https://doi.org/10.1016/B978-0-12-817052-6.00009-4

14. Gizaw, S., M. Woldehanna, H. Anteneh, G. Ayledo, F. Awol, G. Gebreyohannes, B. Gebremedhin and Wieland B., 2021. "Animal Health Service Delivery in Crop-Livestock and Pastoral Systems in Ethiopia." Frontiers in Veterinary Science 8: 596. https://doi.org/10.3389/fvets.2021.601878

15. Garnsworthy, P., J. Craigon, J. Hernandez-Medrano and Saunders N., 2012. "Variation among individual dairy cows in methane measurements made on farm during milking." Journal of dairy. science 95(6): 3181-3189. https://doi.org/10.3168/jds.2011-4606

16. Gizaw, S., H. Desta, B. Dagim and Wieland B., 2019. "A narrative review of animal health interventions for designing herd health interventions for Ethiopia."https://creativecommons.org/licenses/ by/4.0.

17. Guadu, T. and Abebaw M., 2016. "Challenges, opportunities and prospects of dairy farming in Ethiopia: A review." World Journal of Dairy \& Food Sciences 11(1): 01-09. DOI: 10.5829/idosi.wjdfs.2016.11.1.10140

18. Hair, E., T. Halle, E. Terry-Humen, B. Lavelle and Calkins J., 2006. "Children's school readiness in the ECLS-K: Predictions to academic, health, and social outcomes in first grade."EarlyChildhoodResearchQuarterly21(4):431-454. doi.org/10.1016/j.ecresq.2006.09.005

19. Henchion, M., M. Hayes, A. M. Mullen, M. Fenelon and Tiwari B., 2017. "Future protein supply and demand: strategies and factors influencing a sustainable equilibrium." Foods 6(7): 53. https://doi.org/10.3390/foods6070053

20. JANETRIX, M. L., 2019. DETERMINANTS OF ADOPTION OF DAIRY FARMING TECHNOLOGIES BY RURAL WOMEN IN KAKAMEGA COUNTY, KENYA, KENYATTA UNIVERSITY.

21. Kline, R. B. 2011. Convergence of structural equation modeling and multilevel modeling, na. DOI: https://dx.doi.org/10.4135/9781446268261.n31

22. Kline, R. B. 1998. "Software review: Software programs for structural equation modeling: Amos, EQS, and LISREL." Journal of psychoeducational assessment 16(4): 343-364.

https://doi.org/10.1177/073428299801600407

23. Knapp, J. R., G. Laur, P. A. Vadas, W. P. Weiss and Tricarico J. M., 2014. "Invited review: Enteric methane in dairy cattle production: Quantifying the opportunities and impact of reducing emissions." Journal of dairy science 97(6): 3231-3261. https://doi.org/10.3168/jds.2013-7234

24. Maini, T. S., 2016. FDI in India: Do New Delhi and state governments need to re-think strategies? South Asia Democratic Forum (SADF).

25. Marshall, K., G. R. Salmon, S. Tebug, J. Juga, M. MacLeod, J. Poole, I. Baltenweck and Missohou A., 2020. "Net benefits of smallholder dairy cattle farms in Senegal can be significantly increased through the use of better dairy cattle breeds and improved management practices." Journal of dairy. science 103(9): 8197-8217. https:// doi.org/10.3168/jds.2019-17334

26. Minten, B., Y. Habte, S. Tamru and Tesfaye A., 2020. "The transforming dairy sector in Ethiopia." Plos one 15(8): e0237456. https://doi.org/10.1371/journal.pone.0237456 
27. Misganaw, A., D. Samuel, A. Efrem and. Beza E. A. B., 2016. "Adoption and impacts of dairy production technologies in Southwest Ethiopia: the cases of Jimma and Ilu-Ababora zones." Journal of Biology, Agriculture and Healthcare 6(7): 1-12. ISSN 2224-3208 (Paper) ISSN 2225-093X (Online)

28. Mor, R. S., A. Bhardwaj, S. Singh and. Nema P. K., 2019. Framework for measuring the performance of production operations in the dairy industry. Managing_Operations Throughout Global Supply Chains, IGI Global: 20-49. DOI: 10.4018/978-1-5225-8157-4.ch002

29. Mor, R. S., A. Bhardwaj, S. Singh and Khan S. A. R., 2021. "Modelling the distribution performance in dairy industry: a predictive analysis." LogForum 17(3). DOI.10.17270/J.LOG.2021.609.

30. Mor, R. S., A. Bhardwaj, S. Singh and Khan S. A. R., 2021. "Modelling the distribution performance in dairy industry:a predictive analysis." LogForum 17(3). DOI.10.17270/J.LOG.2021.609

31. Munyeki, N. and Were S., 2017. "Influence of transformational leadership on the performance of project based organizations: A case of International Livestock Research Institute." International Journal of Project Management 1(3): 41-60

32. Mutua, B. M. 2018. Challenges facing indigenous chicken production and adoption levels of biosecurity measures in selected areas of Makueni County, Kenya. URI: http://repository.seku.ac.ke/handle/123456789/4126

33. Ngarava, S., A. Mushunje and P. Chaminuka (2020). "Qualitative benefits of livestock development programmes. Evidence from the Kaonafatso ya Dikgomo (KyD) Scheme in South Africa."Evaluation and Program Planning 78: 101722. https://doi.org/10.1016/j.evalprogplan.2019.101722

34. Pegolo, S., H. Yu, G. Morota, V. Bisutti, G. J. Rosa, G. Bittante and Cecchinato A.. 2021. "Structural equation modeling for unraveling the multivariate genomic architecture of milk proteins in dairy cattle." Journal of Dairy Science 104(5): 5705-5718. https://doi.org/10.3168/jds.2020-18321

35. Ravindra, K., P. Rattan, S. Mor and Aggarwal A. N., 2019. "Generalized additive models:Building evidence of air pollution, climate change and human health." Environment international 132: 104987. https://doi.org/10.1016/j.envint.2019.104987

36. Seble, W. G., K. Satoko, K. Toshihisa, T. N. Randrianantoandro and Kono H., 2020. "Impact of Training of Small-Scale Dairy Farmers on Milk Production and Income in Ethiopia." Journal of Agricultural Extension 24(3): 1-8. DOI: 10.4314/jae.v24i3.1

37. Sharamo, F. F., H. Shimelis, B. M. OlaOlorun, H. Korir, A. H. Indetie and Mashilo J., 2021. "Determining ethyl methane sulfonate-mediated (EMS) mutagenesis protocol for inducing high biomass yield in fodder barley ('Hordeum vulgare'L.)." Australian Journal of Crop Science 15(7): 983-989. doi/10.3316/informit.154424398224279.

38. Shelly, M., 2020. "Effectiveness of training programme on the adoption behaviour of goat farmers in Punjab." J Krishi Vigyan 9(1): 109-113. DOI : 10.5958/2349-4433.2020.00144.0

39. Soberon, F. and Van Amburgh M., 2017. "Effects of preweaning nutrient intake in the developing mammary parenchymal tissue." Journal of dairy science 100(6): 4996-5004. https://doi.org/10.3168/jds.2016-11826 
40. Soteriades, A. D., P. Faverdin, S. Moreau, T. Charroin, M. Blanchard and Stott A. W., 2016. "An approach to holistically assess (dairy) farm eco-efficiency by combining life cycle analysis with data envelopment analysis models and methodologies." animal 10(11): 1899-1910. DOI: https://doi.org/10.1017/S1751731116000707.

41. Tekeba, E., M. Wurzinger and Zollitsch W., 2014. "Effects of dietary supplementation with urea molasses multi-nutrient block on performance of late lactating local ethiopian and crossbred dairy cows." International Journal of Technology Enhancements and Emerging Engineering Research 2(2): 25-32.

42. Van der Lee, J., S. Oosting, L. Klerkx, F. Opinya and. Bebe B. O., 2020. "Effects of proximity to markets on dairy farming intensity and market participation in Kenya and Ethiopia." Agricultural Systems 184: 102891. https://doi.org/10.1016/j.agsy.2020.102891

43. Wondatir, Z., Y. Mekasha and Wouters B., 2011. "Assessment of productive and reproductive performance of dairy cattle nexus with feed availability in selected peri-urban areas of Ethiopia." Journal of Cell and Animal Biology. 5(15): 308-315. https://doi.org/10.5897/JCAB.9000022

\section{Figures}

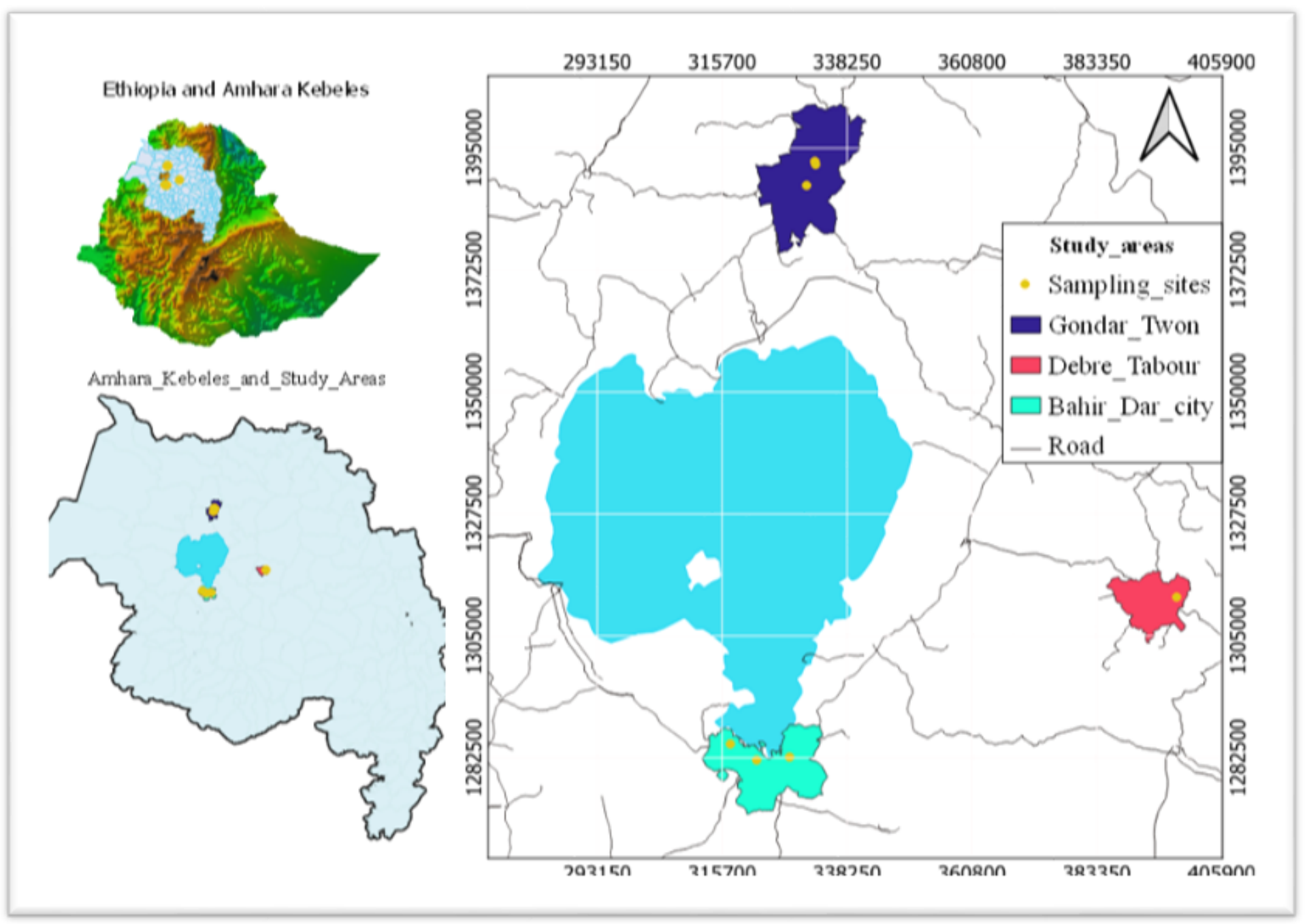


Figure 1

Map of the research area (Amhara region)

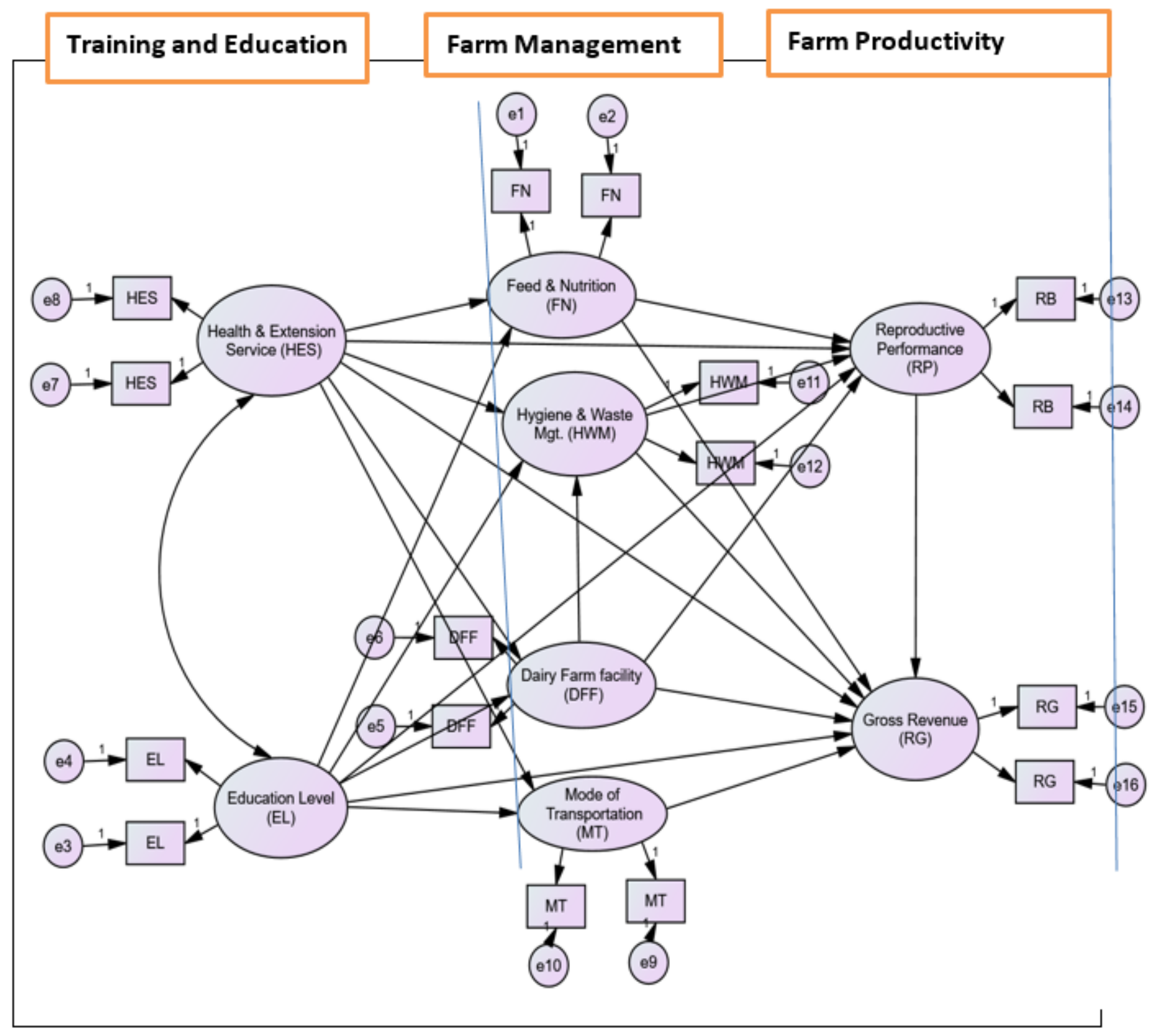

Figure 2

Conceptual framework of the Dairy farm monitoring practice in Amhara region 


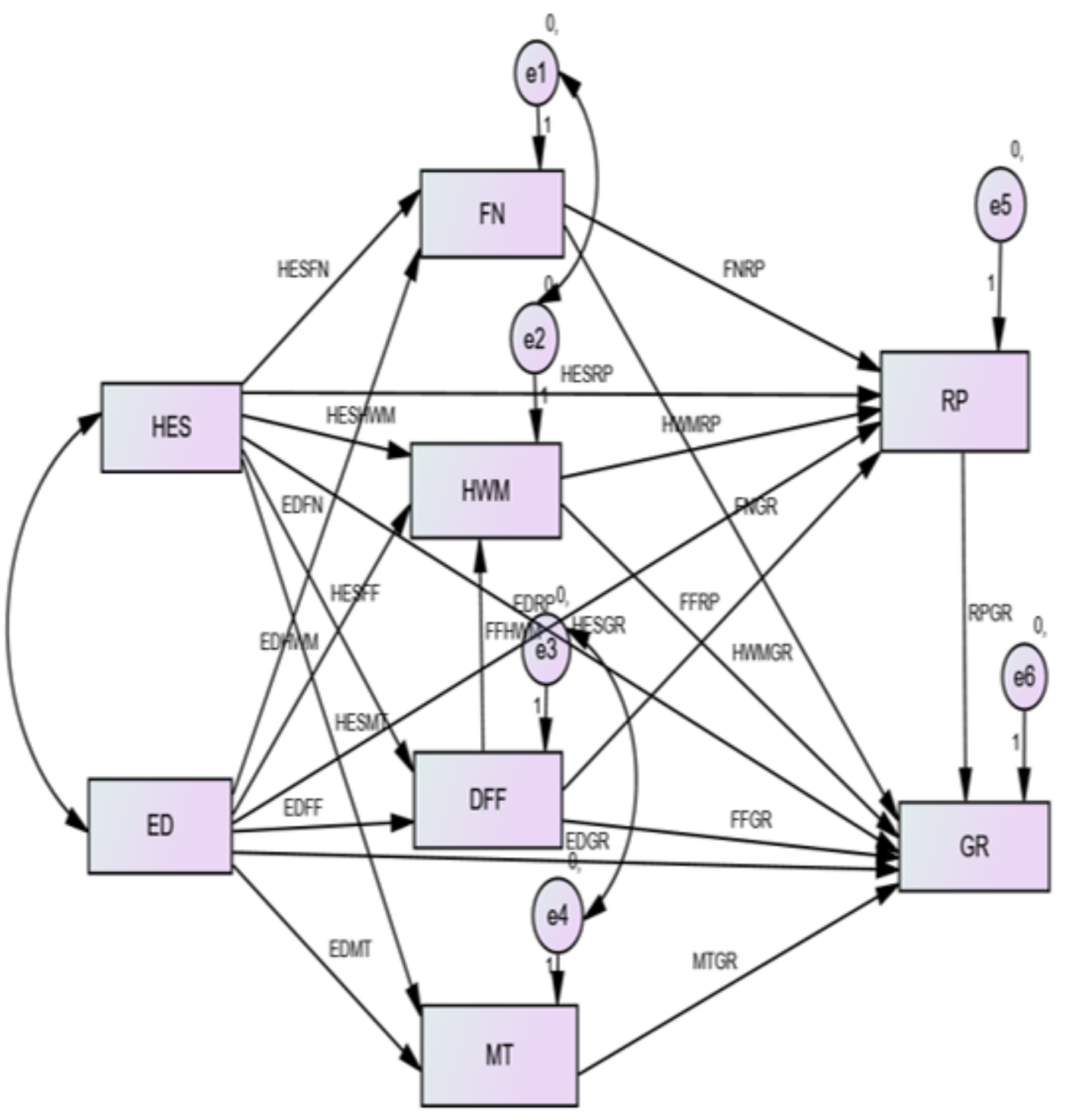

Figure 3

Dairy farm monitoring practice in structural equation Model (SEM) 